\title{
Assessment of the Impact Hazard of the Array Taking Into Account the Geological Features of the Structure of Electric Profiles
}

\author{
Konstantin Dudko ${ }^{1}$, Alexey Shikanov ${ }^{1}$, and Yuri Lesin ${ }^{1}$ \\ ${ }^{1}$ T.F. Gorbachev Kuzbass State Technical University, 650000, 28 Vesennyaya St., Kemerovo, Russia
}

\begin{abstract}
The current geodynamic situation at the Tashtagol iron ore Deposit is considered. The impact hazard of the array was determined using electrometric coefficients obtained taking into account the geological structure of the array. An assessment of the correspondence of the obtained coefficients to actually registered geodynamic phenomena was made.
\end{abstract}

\section{Introduction}

The experience of mining all ore deposits in Western Siberia shows that with increasing depth of mining operations, there is an increase in the intensity and frequency of manifestations of mountain pressure in a dynamic form. The most representative in terms of manifestations of dynamic phenomena is Tashtagolskoe field.

A total of 595 events with an energy of more than $100 \mathrm{~J}$ were recorded at the Tashtagolsky mine during the period from February 2018 to August 2019 within the horizon (-350), with more than $70 \%$ of them occurring below the horizon $(-300)$. Their distribution by month and energy class is shown in table 1 . At the same time, during the period under review, there is an increase in cases of mountain pressure manifestations in the workings, and there is an increase in energy and the approach of the foci of events to the workings.

Table 1. Distribution of geodynamic events by month and energy class within the horizon (-350) for the period from 01.02.18 to 30.08.19.

\begin{tabular}{|l|c|c|c|c|c|c|c|c|}
\hline \multirow{2}{*}{ Date } & \multicolumn{6}{|c|}{ Energy class of a geodynamic event } & \multirow{2}{*}{$\begin{array}{c}\text { Violation of fas- } \\
\text { tening of mine } \\
\text { workings }\end{array}$} & Total \\
\cline { 2 - 8 } & $\mathbf{2}$ & $\mathbf{3}$ & $\mathbf{4}$ & $\mathbf{5}$ & $\mathbf{6}$ & $\mathbf{7}$ & - & 32 \\
\hline February 2018 & 27 & 4 & 1 & - & - & - & - & 6 \\
\hline March 2018 & 6 & - & - & - & - & - & - & 10 \\
\hline April 2018 & 8 & 2 & - & - & - & - & - & 8 \\
\hline May 2018 & 4 & 3 & 1 & - & - & - & - & 18 \\
\hline June 2018 & 9 & 6 & 2 & 1 & - & - & - & - \\
\hline
\end{tabular}




\begin{tabular}{|l|c|c|c|c|c|c|c|c|} 
July 2018 & 11 & 5 & 2 & - & 1 & - & - & 19 \\
\hline August 2018 & 9 & 1 & 2 & - & - & - & - & 12 \\
\hline September 2018 & 13 & 4 & 1 & - & - & - & - & 18 \\
\hline October 2018 & 12 & - & - & - & - & - & - & 12 \\
\hline November 2018 & 18 & 1 & - & - & - & - & - & 19 \\
\hline December 2018 & 4 & 5 & - & - & - & - & - & 9 \\
\hline January 2019 & 11 & - & 4 & 1 & - & - & - & 16 \\
\hline February 2019 & 30 & 12 & - & 2 & 1 & - & + & 45 \\
\hline March 2019 & 29 & 11 & 2 & 1 & - & - & + & 43 \\
\hline April 2019 & 25 & 9 & 1 & - & - & - & - & 35 \\
\hline May 2019 & 69 & 12 & 4 & - & 3 & - & + & 88 \\
\hline June 2019 & 47 & 8 & 1 & - & 2 & - & + & 58 \\
\hline July 2019 & 75 & 12 & 3 & - & - & 1 & + & 91 \\
\hline August 2019 & 37 & 13 & 3 & 1 & - & 2 & + & 56 \\
\hline Subtotal & 444 & 108 & 27 & 6 & 7 & 3 & 6 & + \\
\hline
\end{tabular}

At the same time, during the period under review, there is an increase in cases of mountain pressure manifestations in the workings (table 2), and there is an increase in energy and the approach of the foci of events to the workings.

Table 2. The manifestation of rock pressure.

\begin{tabular}{|c|c|c|c|c|}
\hline $\begin{array}{c}\text { Geodynamic } \\
\text { events }\end{array}$ & Date & Energy, J & Energy class & $\begin{array}{c}\text { Manifestation of the } \\
\text { rock pressure }\end{array}$ \\
\hline 1 & 28.02 .2018 & 1442374 & 6.2 & \multirow{8}{*}{$\begin{array}{l}\text { Violation of fastening } \\
\text { of mine workings }\end{array}$} \\
\hline 2 & 06.02 .2019 & 5516.046 & 3.6 & \\
\hline 3 & 26.03.2019 & 365907.4 & 5.6 & \\
\hline 4 & 17.05.2019 & 35910.68 & 4.6 & \\
\hline 5 & 16.06 .2019 & 14762.41 & 4.2 & \\
\hline 6 & 30.06 .2019 & 2190742 & 6.3 & \\
\hline 7 & 21.07 .2019 & 70076416 & 7.8 & \\
\hline 8 & 16.08 .2019 & 41717324 & 7.6 & \\
\hline
\end{tabular}

Currently, at the mines, in particular, at tashtagolskoye, for the regional forecast of the degree of impact hazard of the array, it is carried out mainly by methods of Electrometry and microseismics. The foreign experience of recent years is mainly limited to the coal deposits of China and Poland [1-10] and is based on the study of similar individual issues, while focusing on the technology of mining and the mechanism of formation of a mining shock, rather than its forecast. The impact hazard of the array during electrometric measurements at the 
first stage is determined by the value of the electrometric coefficient $K_{\rho}^{*}=\rho_{c p} / \rho_{u}$, where $\rho_{c p}$ - the average value of the CUES for the entire measuring profile or for each structural block, $\rho_{\mu}$ - the average value of CUES in the absence of geodynamic phenomena. When the coefficient is set $K_{\rho}^{*}<1$ in controlled workings, special measures are taken to identify impact-prone areas of the array.

\section{Theoretical part of the question}

However, the iron ore deposits of the Mountain Shoria are represented by a large number of vertical or steeply falling contacts between rocks that compose the array around the mine workings, and the electric profile lines laid along their sides intersect a set of fairly welldefined vertical (steeply falling) rock layers. When an electric current flows or electromagnetic waves propagate through a layered medium, reflection and refraction phenomena are observed at the contacts of the layers, which affects the distribution of the CUES along the measuring profile. Thus, this array should be represented as an alternation of vertical homogeneous isotropic layers of rocks [11-13]. If the electrical resistance of the I - th layer is equal to

$$
R_{i}=\rho_{k i} / h_{i}
$$

then the entire layered array should be represented as a parallel connection $n$ resistors with resistance $R_{i}$ each layer. Then the total (equivalent) resistance of the array $R_{\text {equ }}$ will be equal to:

$$
\frac{1}{R_{\text {equ }}}=\frac{1}{R_{1}}+\frac{1}{R_{2}}+\ldots+\frac{1}{R_{n}}=\sum_{i=1}^{n} \frac{1}{R_{i}}
$$

Subject to (1) formula (2) will take the form:

$$
\rho_{k(\text { equ })}=\frac{\sum_{i=1}^{n} h_{i}}{\frac{h_{1}}{\rho_{k 1}}+\frac{h_{2}}{\rho_{k 2}}+\ldots+\frac{h_{i}}{\rho_{k n}}}
$$

A similar approach to accounting for the number of layers and replacing their set with one equivalent is used in the theory of grounding devices, especially when designing grounding and lightning protection systems.

\section{Results and discussion}

Using the formula (3), the electrometric measurements were recalculated for all controlled workings (Cargo and Empty crosscut, South-Eastern field drift) on the horizon (-350). Table 3 shows the results of this recalculation and a comparison of the obtained electrometric coefficients based on the arithmetic mean of the CUES $K_{\rho}^{*}$ and taking into account the geological structure of the array $K_{\rho}^{* *}$. 
Table 3. Results of recalculation and comparison of electrometric coefficients Tashtagolsky mine for the period from 01.02 .18 to 30.08 .19 .

\begin{tabular}{|c|c|c|c|c|c|c|}
\hline \multirow{2}{*}{ Date of measurement } & \multicolumn{2}{|c|}{ South-East field drift } & \multicolumn{2}{|c|}{ Cargo crosscut } & \multicolumn{2}{c|}{ Empty crosscut } \\
\cline { 2 - 7 } & $K_{\rho}^{* *}$ & $K_{\rho}^{*}$ & $K_{\rho}^{* *}$ & $K_{\rho}^{*}$ & $K_{\rho}^{* *}$ & $K_{\rho}^{*}$ \\
\hline 14.02 .2018 & 0.51 & 1.48 & 0.41 & 0.69 & 1.04 & 1.31 \\
\hline 13.03 .2018 & 0.37 & 1.07 & 0.25 & 0.43 & 0.91 & 1.10 \\
\hline 07.05 .2018 & 0.62 & 1.13 & 0.39 & 0.77 & 0.61 & 1.04 \\
\hline 05.06 .2018 & 0.30 & 1.00 & 0.22 & 0.43 & 0.36 & 0.66 \\
\hline 02.07 .2018 & 1.68 & 2.19 & 1.70 & 2.11 & 0.90 & 1.48 \\
\hline 30.07 .2018 & 2.40 & 3.08 & 0.44 & 0.53 & 1.52 & 2.36 \\
\hline 07.08 .2018 & 0.82 & 1.46 & 0.99 & 1.34 & 0.38 & 1.06 \\
\hline 14.09 .2018 & 0.66 & 1.07 & 0.71 & 1.08 & 0.31 & 0.77 \\
\hline 04.10 .2018 & 1.76 & 2.27 & 0.85 & 1.30 & 0.34 & 0.83 \\
\hline 23.11 .2018 & 1.09 & 2.01 & 1.28 & 1.63 & 0.42 & 1.12 \\
\hline 04.12 .2018 & 2.87 & 3.04 & 1.95 & 2.13 & 0.84 & 1.31 \\
\hline 10.01 .2019 & 0.53 & 1.15 & 0.45 & 0.90 & 0.31 & 0.98 \\
\hline 07.02 .2019 & 1.07 & 1.66 & 0.63 & 1.24 & 0.23 & 0.81 \\
\hline 05.03 .2019 & 0.85 & 1.33 & 0.40 & 0.43 & 0.43 & 0.67 \\
\hline 02.04 .2019 & 0.75 & 1.25 & 0.42 & 0.94 & 0.27 & 0.98 \\
\hline 27.05 .2019 & 0.37 & 0.88 & 0.33 & 0.89 & 0.69 & 1.13 \\
\hline 10.06 .2019 & 0.27 & 0.72 & 0.56 & 1.21 & 0.49 & 1.07 \\
\hline 02.07 .2019 & 0.60 & 0.98 & 0.75 & 1.24 & 0.60 & 1.01 \\
\hline 23.08 .2019 & 0.40 & 0.80 & 0.27 & 0.63 & 0.40 & 0.71 \\
\hline
\end{tabular}

Electrometric values of the coefficients $K_{\rho}^{* *}$ on average, by $40 \%$, and in some cases by $70 \%$ reduced, compared to $K_{\rho}^{*}$. The quantitative distribution of the obtained qualitative characteristics of the impact hazard of the array is presented in table 4. 
Table 4. Quantitative distribution of qualitative characteristics of rockburst hazard in the array

Tashtagol Deposit for the period from 01.02 .18 on 30.08 .19 year.

\begin{tabular}{|c|c|c|c|c|c|c|}
\hline \multirow{2}{*}{$\begin{array}{c}\text { Data processing } \\
\text { methods } \\
\\
\text { Quality indica- } \\
\text { tors } \\
\text { possible mani- } \\
\text { festations of ge- } \\
\text { odynamic phe- } \\
\text { nomena }\end{array}$} & \multicolumn{3}{|c|}{$\begin{array}{l}K_{\rho}^{*}-\text { electrometric coefficient deter- } \\
\text { mined according to the current instruc- } \\
\text { tions }\end{array}$} & \multicolumn{3}{|c|}{$\begin{array}{l}K_{\rho}^{* *} \text { - electrometric coefficient de- } \\
\text { termined with consideration of the ge- } \\
\text { ological structure of the electric pro- } \\
\text { file }\end{array}$} \\
\hline & $\begin{array}{c}\text { There is no } \\
\text { possibility } \\
\text { of geody- } \\
\text { namic phe- } \\
\text { nomena } \\
\text { occurring } \\
\text { in the rock } \\
\text { mass }\end{array}$ & $\begin{array}{l}\text { Local } \\
\text { stress con- } \\
\text { centration } \\
\text { is carried } \\
\text { out in the } \\
\text { rock mass }\end{array}$ & $\begin{array}{l}\text { Possible geo- } \\
\text { dynamic phe- } \\
\text { nomena of } \\
\text { class } 3 \text { and } 5\end{array}$ & $\begin{array}{c}\text { There is } \\
\text { no possi- } \\
\text { bility of } \\
\text { geody- } \\
\text { namic } \\
\text { phenom- } \\
\text { ena oc- } \\
\text { curring } \\
\text { in the } \\
\text { rock } \\
\text { mass }\end{array}$ & $\begin{array}{l}\text { Local stress } \\
\text { concentra- } \\
\text { tion is car- } \\
\text { ried out in } \\
\text { the rock } \\
\text { mass }\end{array}$ & $\begin{array}{c}\text { Possible } \\
\text { geody- } \\
\text { namic phe- } \\
\text { nomena of } \\
\text { class } 3 \text { and } \\
5\end{array}$ \\
\hline Quantity & 35 & 19 & 3 & 9 & 20 & 28 \\
\hline
\end{tabular}

Electrometric coefficient $K_{\rho}^{* *}$ four times less often pointed to the absence of the possibility of geodynamic phenomena and nine times more often - on the possibility of occurrence of geodynamic phenomena above the third class. Figure 1 shows more clearly the comparison of average values of electrometric coefficients $K_{\rho}^{* *}$ for the horizon (-350). The graph clearly shows three periods characterized by a reduced (from October to December 2018) and increased geodynamic activity of the array (from February to September 2018 and from January to August 2019). In this case only the average values of the electrometric coefficients $K_{\rho}^{* *}$ in most cases they demonstrate compliance with registered geodynamic phenomena.

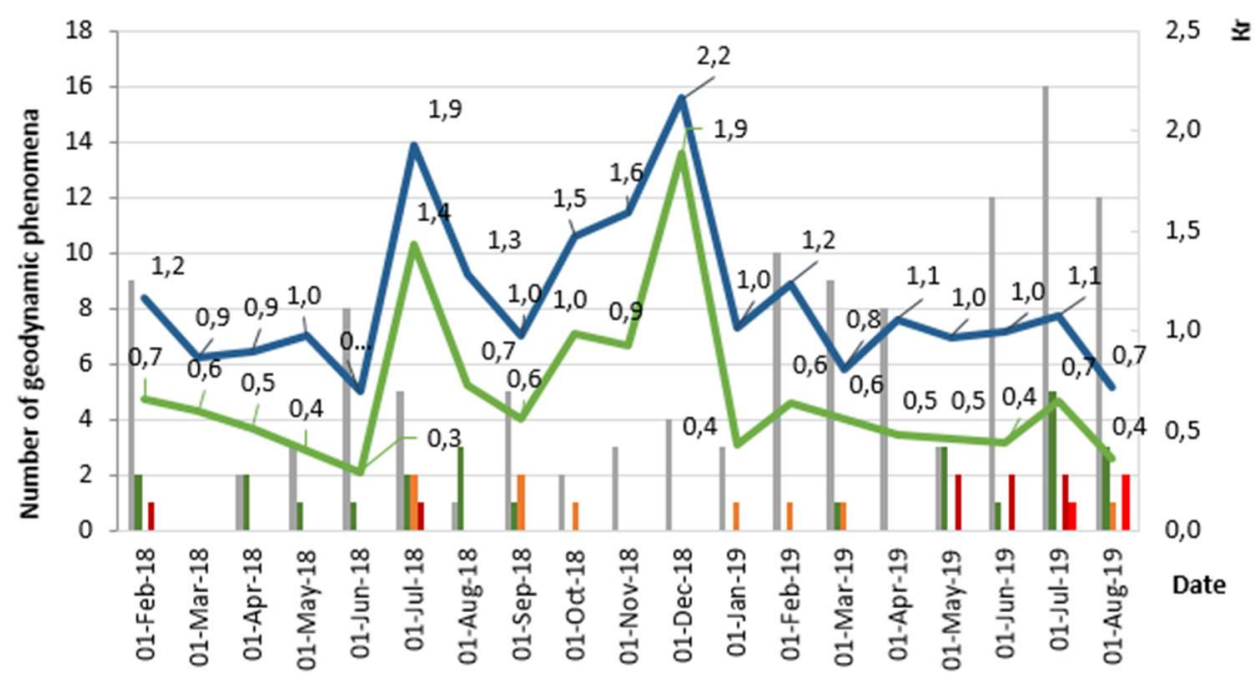

3 class 4 class 5 | class 6 | class 7 class

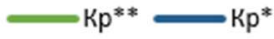

Fig. 1. Electrometric coefficients $\left(K_{\rho}{ }^{*}\right.$ and $K_{\rho}{ }^{* *}$ ) and geodynamic phenomena for the period from 01.02.2018 to 30.08.2019. 
This is also evidenced by data on average values $K_{\rho}{ }^{* *}$ for the horizon (-350) for recorded geodynamic phenomena shown in table 5 .

Table 5. Correspondence of registered geodynamic phenomena to electrometric coefficients $K_{\rho}^{* *}$

\begin{tabular}{|c|c|c|c|c|}
\hline $\begin{array}{l}\% \\
\text { p. p. }\end{array}$ & $\begin{array}{c}\text { Date of } \\
\text { measurement }\end{array}$ & $K_{\rho}^{* *}$ & $\begin{array}{c}\text { The presence of geo- } \\
\text { dynamic phenomena } \\
\text { is higher } \\
\text { third class }\end{array}$ & $\begin{array}{l}\text { Correspondence of geodynamic } \\
\text { phenomena to electrometric coeffi- } \\
\text { cients }\end{array}$ \\
\hline 1 & February 2018 & 0.7 & yes & Confirms \\
\hline 2 & March 2018 & 0.6 & no & Not confirmed \\
\hline 3 & April 2018 & 0.5 & yes & Confirms \\
\hline 4 & May 2018 & 0.4 & yes & Confirms \\
\hline 5 & June 2018 & 0.3 & yes & Confirms \\
\hline 6 & July 2018 & 1.4 & yes & Not confirmed \\
\hline 7 & August 2018 & 0.7 & yes & Confirms \\
\hline 8 & $\begin{array}{l}\text { September } \\
2018\end{array}$ & 0.6 & yes & Confirms \\
\hline 9 & October 2018 & 1.0 & yes & Not confirmed \\
\hline 10 & $\begin{array}{l}\text { November } \\
2018\end{array}$ & 0.9 & no & Confirms \\
\hline 11 & $\begin{array}{l}\text { December } \\
2018\end{array}$ & 1.9 & no & Confirms \\
\hline 12 & January 2019 & 0.4 & yes & Confirms \\
\hline 13 & February 2019 & 0.6 & yes & Confirms \\
\hline 14 & March 2019 & 0.6 & yes & Confirms \\
\hline 15 & April 2019 & 0.5 & no & Not confirmed \\
\hline 16 & May 2019 & 0.5 & yes & Confirms \\
\hline 17 & June 2019 & 0.4 & yes & Confirms \\
\hline 18 & July 2019 & 0.7 & yes & Confirms \\
\hline 19 & August 2019 & 0.4 & yes & Confirms \\
\hline
\end{tabular}

Table 5 shows that out of 19 measurements, the discrepancy between the electrometric coefficient $K_{\rho}^{* *}$ and the registered geodynamic phenomena was found in four cases.

\section{Conclusion}

Thus, processing of measurement results taking into account the geological structure of electrophiles significantly approximates the electrometric forecast to the real assessment of the seismic events that occurred. The forecast efficiency increases to $80 \%$.

\section{References}

1. Q. Qihu, Scholl of engineering bulletin, 3, 109-117 (2014)

2. C. Wang, Evolution, Monitoring and Predicting Models of Rockburst: Precursor Information for Rock Failure (Springer, New York, 2018)

3. L. Dou, Z. Mu, Zh. Li, A. Cao, S. Gong, International Journal of Coal Science \& Technology, 1, 278-288 (2014)

4. R. Patyńska1, A. Mirek, Z. Burtan, E. Pilecka, E3S Web Conf., 36, 1-8 (2018)

5. F. Xia-Ting, Rockburst: Mechanisms, Monitoring, Warning, and Mitigation (ButterworthHeinemann, Berlin, 2018) 
6. Z. Li, X. He, L. Dou, G. Wang, Geosciences Journal, 22, 623-639 (2018)

7. Wei Shen, Lin-ming Dou, H. He, G. Zhu, Arabian Journal of Geosciences, 10, Article number: 196 (2017)

8. A. Cao, L. Dou, Ch.Wang, X. Yao, J. Dong, Y. Gu, Rock Mechanics and Rock Engineering, 49, 4407-4422 (2016)

9. C. Lu, L. Dou, N. Zhang, J. Xue, G. Liu, Natural Hazards, 73 (2014)

10. J. He , L. Dou, A. Cao , S. Gong, J. Lü, Journal of Central South University, 19, 1086$1091(2012)$

11. D. Szurgacz, J. Brodny, Sustainability, 11(9), 2570 (2019) DOI: doi.org/10.3390/su11092570

12. D. Szurgacz, J. Brodny, Energies, 12(20), 3945 (2019) DOI: doi.org/10.3390/en12203945

13. D. Szurgacz, J. Brodny, Energies, 13(2), 405 (2020) DOI: https://doi.org/10.3390/en13020405 